\title{
In Vitro Induction and Assessment of Tetraploid Plants From Shoot Cultures of Diploid Niger (Guizotia Abyssinica (L.f.) Cass): a Multipurpose Oilseed Crop
}

\author{
Mahadev Ramkisan Chambhare \\ Savitribai Phule Pune University \\ Tukaram Dayaram Nikam ( $\square$ tdnikam@unipune.ac.in ) \\ Savitribai Phule Pune University https://orcid.org/0000-0002-0236-1489
}

\section{Research Article}

Keywords: Chromosome. Colchicine. Oil seed. Guizotia. Tetraploidy

Posted Date: June 23rd, 2021

DOI: https://doi.org/10.21203/rs.3.rs-623340/v1

License: (c) (1) This work is licensed under a Creative Commons Attribution 4.0 International License. Read Full License

Version of Record: A version of this preprint was published at Plant Cell, Tissue and Organ Culture (PCTOC) on November 24th, 2021. See the published version at https://doi.org/10.1007/s11240-02102200-5. 


\section{Abstract}

Agronomic traits improvement in crop plant can be accomplished by induction of polyploidy. Niger (Guizotia abyssinica (L.f.) Cass.) is one of the important edible oil yielding diploid crop $(2 n=30)$. In the present study, the tetraploidization in Niger plants was achieved by treating apical portion of in vitro raised shoots with colchicine and their confirmation by chromosome counting and flow cytometry. The in vitro shoots were raised from leaf explants on MS medium supplemented with $1.0 \mathrm{mg} / \mathrm{l} \mathrm{BAP} \mathrm{(6-}$ benzylaminopurine). The survival and nature of growth of treated shoots was variable with colchicine concentration $(0.0,0.005,0.01,0.02,0.03$, and $0.04 \%)$ and exposure time $(4,8,12$, and $16 \mathrm{~h})$. The maximum tetraploid induction ratio was recorded with $0.02 \%$ colchicine treatment for $8 \mathrm{~h}$ which yielded $38.4 \%$ tetraploids. The chromosome number in root cells of tetraploid plantlets was $2 n=4 x=60$ and the DNA content in leaf cells was $10.34 \mathrm{pg}$ which was double to the diploid plant (4.70 pg) cells. In addition, there was significant difference exist in leaf characteristics of diploid and tetraploid plantlets. Compared

to diploid plantlets, the tetraploid plantlets showed larger leaves, larger stomatal size, low stomatal index, larger capitula, larger seeds, and a greater number of seeds per capitula. The oil content in seeds was higher and associated with altered fatty acid profile. The results demonstrated that the tetraploid plantlets obtained in this study exhibited some superior agronomical traits (as mentioned above) compared to diploid. The developed protocol and produced tetraploid plantlets will open the new door in improvement of edible oil yielding crop Guizotia abyssinica (L.f.) Cass.

\section{Key Messages}

Tetraploid plantlets of Niger (Guizotia abyssinica Cass.) produced for the first-time using colchicine and in vitro technique exhibited superior agronomical traits compared to parent diploid. Tetraploidization could increase the dimensions of leaf, stomata, inflorescence, seed and seed oil.

\section{Introduction}

The occurrence of polyploid nature improves the capacity of the plant systems to cope up with the variations in the environments. The polyploid plants contain three or more sets of chromosomes in a single cell and are heritable (Van de Peer 2017; Gantait and Mukherjee 2021). It is projected that polyploidy events appeared naturally in a wide range of taxa and it has significant role in the evolution and crop improvement (Marchant et al. 2016). During past few decades, artificial polyploidization has played a key role in plant breeding and crop improvement. The improvement in agronomic traits was possible in polyploids due to their superiority in physiological and morphological fitness compared to their natural diploids (Sattler et al. 2016; Wei et al. 2017). Polyploids often exhibit improved agronomic traits such as increased vigor, improved productivity, enhanced tolerance to environmental stresses, pest and pathogens, higher metabolite production as well as restoration of fertility in wide hybrids (Javadian et al. 2017). As a consequence, many important crop species has been improved by synthetic induction of polyploidy. Therefore, induction of synthetic polyploidy is a powerful tool for crop improvement. In past few decades, among many available induction methods, the technique of exposing plant cells and tissue 
to colchicine, oryzalin, and trifluralin in vitro has been reported in several cases (Podwyszynska et al. 2017; Zeng et al. 2019). Colchicine is an alkaloid functions as antimitotic metabolite. It is commonly used for chromosome doubling and for the induction of polyploidy in plant cells. Compare to classical methods, tissue culture techniques have been recognized as a powerful tool for breeding research. The technique offers an effective condition for mutant treatment, excellent mechanism for the manipulation of ploidy level by minimizing the influence of external factors during the treatment for chromosome doubling, and increases the efficiency of induction of polyploidy. It allows development of improved genotype on in vitro selection, multiplication of mutant and its establishment in the field conditions.

Niger (Guizotia abyssinica Cass. family- Asteraceae) is an edible oilseed yielding crop. It is cultivated in the tropics and subtropics in Africa and Asia, is one of the best sources of edible oil in Ethiopia and India. In addition, the seeds are also used for making chatni, pickles and used as condiments (Geleta et al. 2007; Patil et al. 2013). This crop is highly-priced because of its edible oil containing useful and rare polyunsaturated fatty acids such as omega-3 and omega-9 fatty acids (linoleic and oleic acids). These fatty acids are not synthesized in the human body (monogastric animals). The oil is also utilized as cardiotonic for mankind which has been proved clinically. However, the major limitation of Niger is low productivity (Nikam and Shitole 1997; Surve et al. 2013; Ahmad et al. 2016). Literature survey revealed that very little efforts have been made for selection and cultivation of superior clones and improvement of species using classical breeding methods as well as genetic engineering approaches (Ghane et al. 2014). Therefore, it is necessary to use the biotechnological tools together with conventional breeding methods to ensure the improvement of Niger crop yield and other agronomical traits. Efficient in vitro propagation protocol provides an ideal platform for manipulation of ploidy levels which is reported for different cultivars of Niger such as Esete, Fogera, GA-8, GA-9, IGP-76, JNC-1, JNC-6, No. 71, ONS-124, Ootacamund, and Shambu, (Nikam and Shitole 1993; 1997; Bhat and Murthy 2007; Disasa et al. 2011; Baghel and Bansal 2014). Guizotia abyssinica is characterized by diploid set of chromosomes therefore polyploidy can be induced by treatment with polyploidy inducing agents. Colchicine is proved to be highly effective chemical compound for induction of polyploidy in plants (Nebel 1937; Dhooghe et al. 2011; Gantait and Mukherjee 2021). Several studies work out and reported the protocol for induction of polyploidy. However, they demonstrate that every plant species responds differently to the colchicine treatment and showed the need of selection and optimization of antimitotic agent concentration, treatment duration, type of explant, exposure method, and regeneration mode employed (Zeng et al. 2019). Although, Niger is an important source of edible oil, there are no attempts on establishment of protocol on induction of polyploidy so far. Polyploid induction and improvement of Niger may help to satisfy the demand of edible oil and industrial oil for the preparation of commercial products as well as to help in the improvement of the economy of farmers.

\section{Material And Methods}

\section{Plant material}


The certified seeds of Niger were procured from Zonal Agricultural Research Station, Igatpuri, Nashik (No. ADR/ZARS/Niger/seed./1088/2017), India. Seeds were surface sterilized with $0.1 \%(\mathrm{w} / \mathrm{v}) \mathrm{HgCl}_{2}$ solution for $5 \mathrm{~min}$, and rinsed with sterile distilled water for 5 times to remove the traces of $\mathrm{HgCl}_{2}$. Surface sterilized seeds were germinated on medium containing 3.0\% (w/v) sucrose, $0.8 \%(\mathrm{w} / \mathrm{v})$ agar-agar, and $\mathrm{pH} 5.8$, and culture tubes maintained at $25 \pm 2^{\circ} \mathrm{C}$ temperature, $8 \mathrm{~h}$ photoperiod illuminated by cool fluorescent light $\left(40 \mu \mathrm{mol} \mathrm{m} \mathrm{m}^{-2} \mathrm{~s}^{-1}\right)$. Then, leaves from in vitro germinated seedlings were excised and cultured on MS $+1.0 \mathrm{mg} / \mathrm{l} \mathrm{BAP}$ for multiple shoot formation. The shoot producing cultures from leaf explants were maintained by culturing the leaf explants from four-week-old in vitro raised shoots on MS + $1.0 \mathrm{mg} / \mathrm{I}$ BAP. The four-week-old leaf derived shoots were used as source material for polyploidy induction.

\section{Colchicine treatment, recovery, and maintenance of tetraploid shoots}

The four-week-old in vitro developed shoots apical portion were treated by keeping the shoots in inverted position in liquid shoot regeneration medium (MS $+1.0 \mathrm{mg} / \mathrm{l}$ BAP) enriched with filter sterilized colchicine at concentration of $0.00,0.005,0.01,0.02,0.03$, and $0.04 \%$ and incubated at $25 \pm 2^{\circ} \mathrm{C}$ in light exposure in static condition for $0,4,8,12$, and $16 \mathrm{~h}$. The liquid shoot regeneration medium lacking colchicine served as a control. A total of 21 number of in vitro raised shoots were used per treatment in three replications. At the end of treatment time, the shoots were subjected to post-soaking in liquid MS medium for $10 \mathrm{~min}$ to remove the colchicine traces adhered to the explants and then washed four times with sterilized distilled water. After washing, the shoots were transferred to solid shoot regeneration medium. After four weeks, the survival rate of shoots, and the tetraploid induction rate were obtained. The newly elongated apical portion of shoots during the four weeks of incubation was excised and subculture on fresh shoots

regeneration medium. Subsequently the newly formed shoot and leaf explants were transferred on shoot regeneration medium and multiplication of tetraploid and diploid shoots was carried out over a period of 12 months.

\section{Confirmation of chromosome doubling}

The in vitro produced shoots were checked by flow cytometry to identify level of polyploidy. The leaf sample was used for ploidy level determination. The samples $(0.5 \mathrm{~g})$ were chopped in $1.5 \mathrm{ml}$ ice-cold Galbraith's buffer solution (Galbraith et al. 1983) along with $0.1 \%$ v/v Triton-X100. The suspension of nuclei was filtered using nylon syringe micro-filter $42 \mu \mathrm{m}$; the nuclear DNA was suspended in RNAase A, and stained with propidium iodide, followed by incubation of suspension in dark for $30 \mathrm{~min}$. prior to analysis (Dolezel et al. 2007). The Attune-Acoustic Focusing Flow Cytometer (Life Technologies, Thermo Fisher Scientific) was used to measure the fluorescence intensity of samples. The nuclear genome size was determined by following formula: 2 C DNA content $(\mathrm{pg})$ = sample $\mathrm{G} 1$ peak mean $\mathrm{x}$ standard $2 \mathrm{C}$ DNA content (pg) / standard G1 peak mean.

\section{Counting of chromosome}


Chromosome counting and observation was performed by following squashing method with slight modification described by Tsuro et al. (2016). The root tips 5-7 $\mathrm{mm}$ in length from four days old roots of in vitro grown shoots were excised and placed in ice water for $4 \mathrm{~h}$. After cold treatment, roots were fixed in Carnoys solution for $24 \mathrm{~h}$ at room temperature. Before squash preparation, the roots were hydrolyzed in 1 $\mathrm{N} \mathrm{HCl}$ for $5 \mathrm{~min}$ at room temperature. Then root tips were transferred to distilled water for $15 \mathrm{~min}$. to remove the $\mathrm{HCl}$. Subsequently, root tips were placed on glass slide, followed by removal of root cap, cut about $1.5 \mathrm{~mm}$ root segment towards root cap and discard the rest portion of root. The root segment was stained with one drop of $1 \%$ aceto-carmine solution for $4 \mathrm{~min}$, and squashed under cover glass by application of pressure with the help of thumb. Then the preparation was observed for chromosome number under light microscope at x40 and x100 magnifications (Leica Microsystems DM 3000 LED, Germany).

\section{Morphological and leaf characters}

Tetraploid G. abyssiniica were induced by the treatment of colchicine in the apical shoot tip of diploid $G$. abyssiniica. Mature tetraploid plants and control diploid plants were analyzed for morphological characteristics (Table 3). The well mature leaves from two-month-old diploid and tetraploid hardened plantlets were used for observation of leaf variations. In leaf characteristics, the size, shape, and margin of leaves were measured and compared between hardened diploid and tetraploid plants. The values from 21 plants were used to evaluate each morphological parameter.

\section{Field Emission-Scanning electron microscopy (FE-SEM) analysis for stomata}

For field emission scanning electron microscopy analysis, leaf samples of colchicine induced tetraploid and diploid plants were cut into $1.0 \mathrm{~cm}^{2}$ pieces and fixed in $1.25 \%$ glutaraldehyde (Sigma Aldrich, USA) in phosphate buffer saline (PBS) at room temperature for $12 \mathrm{~h}$. The fixed samples were washed with PBS and followed by dehydration in increasing graded series $(10,25,50,75$, and $100 \%)$ of ethyl alcohol 30 min into each grade (Nikam et al. 2019). The leaf sample pieces were further dried and mounted on aluminum stub with auto-stick carbon tape and coated with gold in an auto fine Sputter Coater machine (Quorum Q150T ES). The gold coated final samples of diploid and tetraploids were subjected to FE-SEM analysis (FEI NOVA NANOSEMNPEP303) operating at 5-10 kV, 3.5 spot size, and ETD detector for surface observations digitized with software: $\mathrm{xT}$ microscope. The recorded observations or photographic evidences were used for the determination of stomatal size $(\mu \mathrm{m})$.

\section{Inflorescence, flower, and seed characteristics}

The polyploidy induced variations in inflorescence, flower, and seed characters of Niger were described according to modified method of Abdoli et al. (2013). The shape and size of sepals, diameter of capitula, number of discs florets, number ray florets, were measured at fully expanded stage of capitula. Number of seeds per capitula, size of seeds and weight of 100 seeds of tetraploid and control diploid plantlets were recorded (Table 3 ) at the time of senescence of ray florets. 


\section{Measurement of biomass}

The in vitro raised control diploid and colchicine induced tetraploid plantlets grown in natural conditions were harvested at the time of initiation of capitulum and fresh weight was recorded. Then the total fresh biomass was dried in an oven at $60^{\circ} \mathrm{C}$ till constant weight obtained. The percent moisture content was determined by using following equation.

Moisture content (\%) = Fresh weight - Dry weight / Fresh weight x 100 (Nikam et al. 2019).

\section{Oil extraction and fatty acid composition}

The husk of dry seeds was removed and $10 \mathrm{~g}$ of seeds without husk were grounded using mortar and pestle. The obtained homogenate was suspended in $20 \mathrm{ml}$ of $\mathrm{n}$-hexane and stirred it overnight using rotary shaker $(80 \mathrm{rpm})$ at $25 \pm 2^{\circ} \mathrm{C}$. Then the suspension was subjected to ultrasonication for $30 \mathrm{~min}$, and filtered through Whatman filter paper No.1. The solvent $n$-hexane was removed by evaporation from the filtrate under reduced pressure using Rota-evaporator system at $45^{\circ} \mathrm{C}$. The obtained oil was weighed and stored in a refrigerator at $4^{\circ} \mathrm{C}$ till further analysis. Transesterification of oil was carried out according to modified method described by Awolu and Layokum (2013). For this purpose, $300 \mathrm{mg}$ of oil sample was mixed with $6.0 \mathrm{ml} 0.5 \mathrm{M} \mathrm{NaOH}$ and refluxed for $5 \mathrm{~min}$ at $60^{\circ} \mathrm{C}$, followed by addition of $7 \mathrm{ml}$ of $\mathrm{KOH}$ and 5 $\mathrm{ml}$ of $\mathrm{n}$-hexane. Then in cooled mixture, $15 \mathrm{ml}$ of saturated $\mathrm{NaCl}$ solution was added and stirred for 30 seconds. The mixture was placed in static condition for $15 \mathrm{~min}$ to separate upper fatty acid methyl ester layer. The upper FAME layer was transferred to GC-MS vial for analysis.

Trans-esterified FAME (100 ul) sample was dissolved in $900 \mu \mathrm{l}$ MS grade n-Hexane, then filtered through syringe-filter $(0.2 \mu)$, and subjected to Gas Chromatography-Mass Spectrometry (Shimadzu TQ 8030) equipped with RTX column and injector AOC-20i S with 150 auto samplers. FAME 37 components miX was used as a standard (Supelco 37 Component FAME Mix, CRM47885, USA). The mass scan range was from 50 to $1080 \mathrm{~m} / \mathrm{z}$ with Triple Quadrupole mass analyzer. GC-MS system was operated by using computer-based software GCMS Real-Time analysis and post run Real-Time analysis. The helium was used as a carrier gas with $1 \mathrm{ml} / \mathrm{min}$ flow rate. The oven temperature of GC was raised successively from $50^{\circ} \mathrm{C}$ to $250^{\circ} \mathrm{C}$ at held for $2 \mathrm{~min}$ and later for 8 min respectively. The MSD detector was used to obtain mass spectrum of compounds with mass scan range 45-450 amu. The total run time was 30 minutes. Identification of fatty acids was done based on the ionized fragments, and molecular mass used to compare the mass spectrum of detected fatty acids with mass spectrum of NIST library (Keskes et al. 2017).

\section{Experimental design and statistical analysis}

All the experiments were arranged in completely randomized design (CRD). Experiments were conducted at least three times with 21 replicates per treatment. The data presented in percentage were normalized by arcsine transformation before performing statistical analysis (Zar 1996, Barmukh and Nikam 2008). Data was analyzed by analysis of variance (ANOVA) to detect significant differences between 
means. Means differing significantly were compared using Duncan's (1995) Multiple Range Test (DMRT) at the $P<0.05$ level of significance. Variability in data has been expressed as mean \pm standard error and significant differences between mean values were indicated by using different alphabets.

\section{Results}

\section{Influence of colchicine on survival and growth of shoots}

The apical portion of four-week-old in vitro regenerated shoots forms leaf explants were exposed to the treatment of colchicine (Fig. 1). The survival percentage and growth of shoots was recorded four weeks after colchicine treatment (Table 1). Survival percentage of cultured shoots was largely influenced by the concentration of colchicine. The survival percentage of shoots was declined with increasing colchicine level. The survival percentage was $88.8 \%$ at colchicine lowest level of $0.005 \%$ and decreased to $23.8 \%$ at the maximum colchicine level of $0.04 \%$. The shoots turned brown black and not showing any sign of growth were recorded to be dead. The first visible influence of colchicine was delayed growth of shoots. The continuation of growth of shoots appeared within 2-4 days in non-treated shoots and 14-21 days in colchicine treated shoots.

\section{Influence of colchicine concentration on induction of polyploidy}

The levels of ploidy in control and colchicine treated shoots determined by flow cytometry are depicted in Table 2 and Fig. 2. The nuclear DNA content and DNA size at G1 stage of diploid plantlet (control) were $4.70 \mathrm{pg}$ and $4536 \mathrm{Mbp}$ respectively that of the induced tetraploid plantlets were $10.34 \mathrm{pg}$ and $9974 \mathrm{Mbp}$ respectively which are double amount of the diploid control plantlet. The ploidy level of selected diploid and tetraploid plantlets was confirmed by chromosome counts using root tips. The diploid control plantlets had chromosome number of $2 n=2 x=30$ (Table 2; Fig. 3) and the tetraploid plantlets had $4 x=60$ (Fig. 3). The maximum percentage of tetraploid induction was $38.4 \%$ and was induced by $0.02 \%$ colchicine treatment for $8 \mathrm{~h}$. The results indicated that average numbers of 5 tetraploid plantlets were produced (Table 1).

\section{Variations in leaf and total biomass}

Regarding leaf morphology and stoma characters 2-month-old control diploid and tetraploid plantlets were observed and the results are presented in Fig. 4,5a and Table 3. The results are consistent with the findings of other studies showing that plants with increased ploidy level had leaves with darker green color, and prominent midrib as compared to plants with a lower ploidy level. Leaf area of tetraploids $\left(42.3 \pm 1.8 \mathrm{~cm}^{2}\right)$ was found to be higher than diploids $\left(24.7 \pm 0.7 \mathrm{~cm}^{2}\right)$ (Table 3$)$. There was significant difference observed between the leaf shape and margin of diploid control and that of the tetraploid plantlets produced from it. In leaf taxonomical characters like wavy and serrate leaf margin, acute leaf apex, and narrow leaf base were observed in colchicine induced tetraploid plants. In leaf shape, diploid plants normally possess an ovate leaf shape while in tetraploids it was also ovate but associate with expansion of middle portion of the leaf (Fig. 5a). Also, significant differences were recorded in stoma 
characters between diploid and tetraploid plantlets (Fig. 4). The significant increase in stomatal size in terms of length $(36.6 \pm 1.3 \mu \mathrm{m})$ and width $(28.6 \pm 0.8 \mu \mathrm{m})$ was observed in tetraploid plantlets as compared to diploid control plantlets (length $24.3 \pm 0.6 \mu \mathrm{m}$ and width $15.1 \pm 0.4 \mu \mathrm{m}$ ). The stomatal frequency was higher in control diploid plantlets for both abaxial $(39 \pm 0.5)$ and adaxial $(26.6 \pm 0.8)$ epidermis than those observed in abaxial $(18.3 \pm 0.8)$ and adaxial $(13.6 \pm 0.6)$ epidermis of tetraploid plantlets (Fig. 4; Table 3 ).

The total biomass production in terms of fresh weight (FW) and dry weight (DW) were recorded of in vitro raised hardened control diploid and tetraploid plants (Table 3 ). The tetraploid plants have resulted into significant increase in FW and DW as compared with diploids. The tetraploid plant had mean percent moisture content $88.1 \pm 1.9 \%$ which was lower to that of control diploids (Table 3 ).

\section{Inflorescence, floral and seed morphology}

The significant differences exhibited in inflorescence, floral and seed morphology between tetraploids and control diploids (Fig. 5c, d, e). Capitulum diameter, length of sepals and seed length increased whereas the number of capitula decreased in tetraploid plants compared with diploid controls. The diameter of capitula $(47.4 \pm 1.5 \mathrm{~mm})$ and length of sepal $(37.4 \pm 1.4 \mathrm{~mm})$ in tetraploids was significantly increased compared to the capitula $(36.4 \pm 1.3 \mathrm{~mm})$, and sepals $(21.5 \pm 1.6 \mathrm{~mm})$ of control diploid plants. The number of ray and disc florets per capitula in tetraploids plants was $9.0 \pm 0.5$ and $43.6 \pm 0.8$ respectively which was higher to that of control diploid plants $(7.66 \pm 0.3$ and $29.6 \pm 0.8)$. Colchicine induced tetraploid plants was produced $54 \pm 1.1$ number of seeds per capitula which were low in number compare to diploid controls plants $(33.6 \pm 2)$. The length of ray floret along with ovary was found to be increased in tetraploids $(19.6 \pm 0.8 \mathrm{~mm}$ ) compared to those of diploid controls $(15.6 \pm 0.8)$ (Table 3 ; Fig. $5 \mathrm{c}$, d, e).

\section{Seed weight and oil content}

The influence of colchicine induced tetraploid nature of plants on seed weight and oil content in Niger are shown in Table 3. The significant increase in 100 seeds weight $(0.82 \pm 0.05 \mathrm{~g})$ and oil content $(4.81 \pm 0.09$

g) was recorded in tetraploid plants compared with control diploids ( 100 seeds weight $0.78 \pm 0.02 \mathrm{~g}$ and oil content $4.2 \pm 0.05 \mathrm{~g}$ ) (Table 3 ). The results showed that, 100 seeds weight and oil content was significantly higher in tetraploid plants as compared to diploids. Single factor ANOVA revealed that percent oil content was significantly higher in tetraploid plants at $P<0.05$ level of significance.

\section{Fatty acid composition}

The FAME composition was found to be significantly differed in tetraploid plants as compared to diploids. The amount of linoleic acid (LA), oleic acid (OA), palmitic acid (PA), and stearic acid (SA) was assessed in diploid and tetraploid plants derived with the treatments of colchicine (Fig. 6, 7). FAME content (linoleic, oleic, palmitic and stearic acid) was significantly enhanced in tetraploid plants. Among the fatty acids (oleic, palmitic, and stearic acids), linoleic acid is a major constituent of Niger seed oil and it was also significantly higher in tetraploids $(34.77 \pm 0.4 \mathrm{mg} / \mathrm{ml})$ as compared to diploids $(26.14 \pm 0.2$ 
$\mathrm{mg} / \mathrm{ml}$ (Fig. 6). The results exhibited that, significant increase in OA, PA and SA content was recorded in tetraploids as compared with diploids. Besides to these all-omega fatty acids, there was detection of essential fumaric acid in the sample.

\section{Discussion}

The tetraploidy plays significant role in plant evolution and comprises a significant approach of diversification and creation of new promising genotypes (Omezzine et al. 2012). The aim of present investigation was to generate a tetraploid genotype of G. abyssinica (Niger) and to evaluate its phenotypic response. The healthy in vitro raised shoots were selected and exposed to various concentrations of colchicine $(0.005,0.01,0.02,0.03$, and $0.04 \%)$ in liquid MS medium containing $1.0 \mathrm{mg} / \mathrm{l}$ BAP for $4,8,12$, and $16 \mathrm{~h}$ was screened for induction of polyploidy. The survival $\%$ was dependent on concentration and duration of treatment. The higher concentration $(0.03$, and $0.04 \%)$ and longer duration $(16 \mathrm{~h})$ of mutagens treatments tended to reduce survival and induction of polyploids in Niger. For instance, the reduction in survival rate was achieved in colchicine exposed Eriobotrya japonica plants (Blasco et al. 2015). The study revealed that, it is possible to produce the tetraploids through in vitro culture by using $0.02 \%$ colchicine concentration for $8 \mathrm{~h}$ treatment (Table 1). Likewise, Kazi et al. (2015) reported, induction of tetraploids using colchicine in flower crops viz. Chrysanthemum, Marigold, Jasmine, Anthurium, Lillium, Rose, Gerbera, Aster, Alstromeria and Orchid. Similarly, using $0.1-0.8 \%$ $(\mathrm{w} / \mathrm{v})$ colchicine treatments to germinating seedlings of Jatropha curcas ex vitro resulted in tetraploid and octaploids production (Niu et al. 2016). The treatment of colchicine to inverted apical shoots in liquid MS medium supplemented with BAP $(1.0 \mathrm{mg} / \mathrm{l})$ along with $3.0 \%$ sucrose was highly effective strategy for tetraploids production in G. abyssinica (Nikam and chambhare 2021)

Flow cytometry is used usually for ploidy analyses through detection of nuclear DNA content and it is held as the most precise technique for ploidy determination (Demtsu et al. 2013). In the present investigation, flow cytometry analysis revealed the colchicine $(0.005,0.01$, and $0.02 \%)$ treated plantlets of G. abyssinica having increased nuclear DNA content as tetraploid level. In vitro clonal propagation techniques offer the capability to multiply putative colchicine induced tetraploids. The flow cytometric analysis of in vitro maintained tetraploid shoots during the successive subcultures and plantlet transferred to natural conditions evidenced that the DNA ploidy level remain stable in all the in vitro raised tetraploid plantlets. In accordance, in Glycyrrhiza glabra, the tetraploids were produced at $0.08 \%$ of colchicine and were confirmed using flow cytometric analysis (Moghbel et al. 2015). Similarly, flow cytometry analysis of shoots of Prunella vulgaris treated with $0.05 \%$ soaking treatment of colchicine for 6 and $12 \mathrm{~h}$ of showed about $57.8 \%$ tetraploids shoot production (Kwon et al. 2014).

The chromosome number counting was performed using microscopic technique; it is a very important step in the identification and confirmation of ploidy level. In many plant species, the ability of chromosome doubling is affected by high concentration treatments of colchicine and also it is plant species dependent response (Ari et al. 2015). Previous literature suggested that, the polyploids were most frequently obtained from diploid plants treated with lower concentrations of colchicine (Tel-zur et al. 
2011, Touchell et al. 2020). These results coincide with our study. For instance, Geoffriau et al. (1997) described the induction of tetraploids in Allium cepa from diploids at low concentration of colchicine and also in Colophospermum mopane (Rubuluza et al. 2007). The attempt of chromosome doubling also reported in Gossypium arboreum (Diploid 2n = 26; tetraploid 4x = 52) (Yang et al. 2015), Echium amoenum (diploid $2 \mathrm{n}=16$; tetraploid $4 \mathrm{x}=32$ ) using low concentrations of colchicine (Azoush et al. 2014). In Roman Chamomile plant (Chamaemelum nobile, $2 \mathrm{n}=18$ ), the in vitro induction of autotetraploids $(4 x=36)$ using lower concentration of colchicine treatment and evaluated its essential oil content in capitulum (Tsuro et al. 2016). In our study, the in vitro chromosome doubling (diploid $2 n=30$ and tetraploid $4 x=60$ ) was observed using low concentrations of colchicine treatment. Additionally, the stomatal characters (length and width) also provide evidence for the colchicine treated plants were tetraploid in nature as compared to diploid ones.

The tetraploids are more beneficial for improvement in desired agronomic and ornamental traits including hypertrophy, leaves, biomass, floral characters, and yield (Pei et al. 2019). The previous studies on polyploidy in crop and ornamental plants described the array of morphological and growth variations in correlation with higher ploidy level such as large-sized flowers, and seeds, stem thickness and other morphological yield traits in Fagopyrum tataricum (Wang et al. 2017). In the present study, the similar morphological traits were recorded in colchicine induced tetraploid plants (Table 3; Fig. 6). The diameter of capitulae, number of seeds per capitulae, the length, and width of seed and weight of 100 seeds were higher in tetraploids as compared with diploids (Table 3). In accordance, the improvement in morphology and flower characters has been significantly correlated with the impact of colchicine on floral characters of genus Leucanthemum (Asteraceae) (Greiner et al. 2012) and of Jatropha curcas (Niu et al. 2016). Similarly, significantly higher seed weight in tetraploid plants of Trifolium alexandrinum and polyploid nature of Brassica napus is associated with improved seed yield and oil content (El-Naby et al. 2012). Recently, several important crops are having greater ploidy level including soybean, oilseed rape, bread wheat, and cotton (Trick et al. 2009). Therefore, the morphological characterization of tetraploids can be used as morphological markers for further breeding programs. Over all, this is attributed to the number of genes get doubled during chromosome doubling which enhance the gene expression level related to specific character (Chen 2007, Zhang et al. 2020). The increase in gene number might have increase the gene activity which results in overall increase of size of cells and reflected with changes in morphological traits.

Besides to correlation of tetraploidy with morphological and floral characters, the traits of seed oil yield and fatty acid content were also assessed in colchicine induced tetraploid and control diploid plants. The fatty acid, linoleic, oleic, palmitic, and stearic acid contents of edible oil are important indicators for evaluating the nutritional value of oil producing seeds. Therefore, in the present study the contents of these fatty acids were determined (Fig. 6). The content of all four fatty acids were higher in tetraploid seed oil compare to that of control diploid seed oil. The major increase was observed in linoleic acid. The obtained results showed that colchicine induced chromosome duplication had a significant influence on fatty acid contents. In accordance, the increased thymol content in essential oil of tetraploid plants compare to that of diploid was observed in Trachyspermum ammi (Noori et al. 2017). Similar

Page 10/23 
improvement in polyunsaturated fatty acid was reported in ethyl methane sulphonate induced polyploids of Brassica napus (Wells et al. 2014). The marked differences were recorded in chemical constituents of essential oil samples of tetraploid Tetradenia riparia (Hannweg et al. 2016). The content of nutritional component viz. crude protein, ether extract, ash, acid detergent fibre, neutral detergent fiber, calcium and phosphorus was higher in in vitro induced tetraploids compare to its parent diploid in Moringa oleifera Lam (Zhang et al. 2020). Thus, it is noted that the process of duplication of chromosomes and polyploidization is associated with changes in genome structure and gene expression. Not only that, it also influences downstream effects on the transcriptome, proteome, and metabolome which results in improvement of phenotypic and other functional traits compare to that of parents (Della and Last 2008; Zhang et al. 2020).

\section{Conclusion}

In this study, for the first time we demonstrate that colchicine treatment $(0.02 \%$ for $8 \mathrm{~h})$ to the apical portion of the in vitro raised shoot had significant influence on induction of tetraploidy in Guizotia abyssinica. The tetraploid plants produced with colchicine treatment shown to increase significantly the size of guard cell, leaf, inflorescence, seed, and oil content of the seed. The increase in size and oil content in seed might therefore be improved by colchicine induced chromosome doubling and the resultant tetraploid nature appeared to be genetically stable on in vitro propagation over 12 months and in plantlets transferred to natural conditions. Thus, Guizotia abyssinica showing the great potential of in vitro technique and colchicine treatment to produce new genotype with higher oil containing seeds and number of seeds per capitula. The developed protocol of tetraploidy induction would be useful for the plant breeders, to facilitate breeding and improvement of the crop.

\section{Declarations}

Conflict of interest The authors declare that they have no conflict of interest

\section{References}

1. Abdoli M, Moieni A, Badi HN (2013) Morphological, physiological, cytological and phytochemical studies in diploid and colchicine-induced tetraploid plants of Echinacea purpurea (L.). Acta Physiologiae Plantarum 35(7):2075-2083

2. Ahmad E, Singh MK, Paul A, Ansari AM, Singh DN (2016) Genetic Studies of Yield and Yield Component of Niger (Guizotia Abyssinica Cass.) in Rainfed Condition of Western Plateau of Jharkhand. International J of Tropical Agriculture 34(4):1127-1133

3. Ari LE, Djapo H, Mutlu N, Gurbuz E, Karaguzel O (2015) Creation of variation through gamma irradiation and polyploidization in Vitex agnus-castus. Scientia Horticulturae 195:74-81

4. Awolu OO, Layokun SK (2013) Optimization of two-step transesterification production of biodiesel from neem (Azadirachta indica) oil. Int J Energy and Environmental Engineering 4(1):39 
5. Azoush S, Kazemitabar SK, Heidari P (2014) Evaluation of polyploidy induced in terms of chlorophyll content and catalase activity in Borage (Echium amoenum Glowacka). Acta Advances in Agricultural Sci 2(2):8-12

6. Baghel S, Bansal YK (2014) Thidiazuron Promotes in vitro Plant Regeneration and Phytochemical Screening of Guizotia Abyssinica Cass. - A Multipurpose Oil Crop. World Journal of Pharmacy and Pharmaceutical Sciences 4(1):1193-1217

7. Barmukh RB, Nikam TD (2008) Promotion of seed germination in Pterocarpus marsupium roxb. Indian J. Plant Physiol. 13(2):143-150

8. Bhat JG, Murthy HN (2007) Factors affecting in-vitro gynogenic haploid production in niger (Guizotia abyssinica (L. f.) Cass.). Plant Growth Regul 52:241-248. DOI 10.1007/s10725-007-9196-9

9. Blasco M, Badenes ML, Naval MM (2015) Colchicine-induced polyploidy in loquat (Eriobotrya japonica (Thunb.) Lindl.). Plant Cell Tiss Org Cult 120:453-461

10. Chen ZJ (2007) Genetic and epigenetic mechanisms for gene expression and phenotypic variation in plant polyploids. Annu Rev Plant Biol. 58:377-406

11. Della PD, Last RL (2008) Genome-enabled approaches shed new light on plant metabolism. Science. 320:479-81

12. Disasa T, Feyissa T, Dagne K (2011) In vitro regeneration of niger (Guizotia abyssinica L.F.) Cass.). Int. J. Biosci. 1(6):110-118

13. Dolezel J, Greilhuber J, Suda J (2007) Estimation of nuclear DNA content in plants using flow cytometry. Nature Protocols 2(9):2233-2244

14. Duncan DB (1955) Multiple range and multiple $F$ tests. Biometrics 11:1

15. Demtsu B, Taychasinpitak T, Wongchaochant S, Manochai B (2013) Induced Mutation by Colchicine Treatment of Somatic Embryos in 'Namwa' Banana (Musa sp. ABB). Internat. Transaction J of Engineering, Managt. Applied Sci. \& Technol. 4(4):311-320

16. Dhooghe, E, Van Laere K, Eeckhaut T, Leus L, Van Huylenbroeck J (2011). Mitotic chromosome doubling of plant tissues in vitro. Plant Cell Tissue Organ Cult. 104, 359-373

17. El-Naby ZA, Mohamed NA, Radwan KH, El-Khishin DA (2012) Colchicine induction of polyploidy in Egyptian clover genotypes. J Am Sci 8(10):221-227

18. Galbraith DW, Harkins KR, Maddox JM, Ayres NM, Sharma DP, Firoozabady E (1983) Rapid flow cytometric analysis of the cell cycle in intact plant tissues. Science 220:1049-1051

19. Gantait s, Mukherjee E (2021) Induced autopolyploidy-a promising approach for enhanced biosynthesis of plant secondary metabolites: an insight Journal of Genetic Engineering and Biotechnology (2021) 19(4):1-13

20. Geleta M (2007) Genetic diversity, phylogenetics and molecular systematics of Guizotia Cass. (Asteraceae). 27

21. Geoffriau E, Kahane R, Bellamy C, Rancillac M (1997) Ploidy stability and in vitro chromosome doubling in gynogenic clones of onion (Allium cepa L.). Plant Science 122(2):201-208 
22. Ghane SG, Lokhande VH, Nikam TD (2014) Growth, physiological, and biochemical responses in relation to salinity tolerance for in vitro selection in oil seed crop Guizotia abyssinica Cass. J of Crop Science and Biotechnology 17(1):11-20

23. Greiner R, Vogt R, Oberprieler C (2012) Phylogenetic studies in the polyploid complex of the genus Leucanthemum Mill. (Compositae, Anthemideae) based on cpDNA sequence variation. Plant Systematics and Evolution 298(7):1407-1414

24. Hannweg K, Visser G, deJager K, Bertling I (2016) In vitro-induced polyploidy and its effect on horticultural characteristics, essential oil composition and bioactivity of Tetradenia riparia. South African J of Botany 106:186-191

25. Javadian N, Karimzadeh G, Sharifı M, Moieni A, Behmanesh M (2017) In vitro polyploidy induction: changes in morphology, podophyllotoxin biosynthesis, and expression of the related genes in Linum album (Linaceae). Planta 245, 1165-1178

26. Kazi NA, Yadav JP, Patil UH (2015) Polyploidy in Flower Crops. Scholarly Res J for Interdisciplinary Studies 3(16):2030-2036

27. Keskes H, Belhadj S, Jlail L, El Feki A, Damak M, Sayadi S, Allouche N (2017) LC-MS-MS and GC-MS analyses of biologically active extracts and fractions from Tunisian Juniperus phoenice leaves. Pharmaceutical Biology 55(1):88-95

28. Kwon SJ, Roy SK, Cho KY, Moon YJ, Woo SH, Kim HH (2014) Tetraploid induction approach induced by colchicine of Prunella vulgaris for. albiflora Nakai. International J of Scientific and Res. Publications 4(12)

29. Marchant DB, Soltis D, Soltis P (2016) Patterns of abiotic niche shifts in allopolyploids relative to their progenitors. New Phytologist 212: 708-718

30. Moghbel N, Borujeni MK, Bernard F (2015) Colchicine effect on the DNA content and stomata size of Glycyrrhiza glabra var. glandulifera and Carthamus tinctorius L. cultured in vitro. J of Genetic Engineering and Biotech 13:1-6

31. Nebel, B. R. (1937) Mechanism of Polyploidy through Colchicine. Nature 14:1101

32. Nikam TD, Chambhare MR (2021) Method of producing tetraploid plant through chemical mutagenesis. Indian 202121010903

33. Nikam TD, Mulye KV, Chambhare MR, Nikule HA, Ahire ML (2019) Reduction in hyperhydricity and improvement in in vitro propagation of commercial hard fibre and medicinal glycoside yielding Agave sisalana Perr. ex Engelm by $\mathrm{NaCl}$ and polyethylene glycol. Plant Cell, Tissue and Organ Culture 138:67-78

34. Nikam TD, Shitole MG (1993) Regeneration of niger (Guizotia abyssinica Cass.) CV Sahyadri from seedling explants. Plant Cell, Tissue and Organ Culture 32:345-349, 1993.

35. Nikam TD, Shitole MG (1997) In vitro plant regeneration from callus of Niger (Guizotia abyssinica Cass.) cv. Sahyadri. Plant Cell Report 17(2):155-158

36. Niu L, Tao YB, Chen MS, Fu Q, Dong Y, He H, Xu ZF (2016) Identification and characterization of tetraploid and octoploid Jatropha curcas induced by colchicine. Caryologia 69(1):58-66 
37. Noori SAS, Norouzi M, Karimzadeh G, Shirkool K, Niazian M (2017) Effect of colchicine-induced polyploidy on morphological characteristics and essential oil composition of ajowan (Trachyspermum ammi L.). PCTOC 130:543-551

38. Omezzine F, Ladhari A, Nefzi F, Harrath R, Aouni M, Haouala R (2012) Induction and flow cytometry identification of mixoploidy through colchicine treatment of Trigonella foenum-graecum L. African $\mathrm{J}$ of Biotechnology 11(98):16434-16442

39. Patil HE, Mali RS, Giri AR, Thawari SB (2013) Genetic improvement in niger (Guizotia abyssinica Cass) by using study of variability, correlation and path analysis. International J Agricultural Sciences 9(2):671-673

40. Pei Y, Yao N, He L, Deng D, Li W, Zhang W (2019) Comparative study of the morphological, physiological, and molecular characteristics between diploid and tetraploid radish (Raphunas sativus L.). Scientia Horticulturae 257:108739

41. Podwyszynska M, Sowik I, Machlanska A, Kruczynska D, Dyki B (2017) In vitro tetraploid induction of Malus $\times$ domestica Borkh. using leaf or shoot explants. Scientia Horticulturae 226:379-388

42. Rubuluza T, Nikolova RV, Smith MT, Hannweg K (2007) In vitro induction of tetraploids in Colophospermum mopane by colchicine. South Afr. J Bot. 73(2):259-261

43. Sattler MC, Carvalho CR, Clarindo WR (2016) The polyploidy and its key role in plant breeding. Planta 243(2):281-296

44. Surve VH, Patel CL, Pisal RR, Chavan AA, Patil PR (2013) Quality studies in Niger (Guizotia abyssinica L. Cass) in relation to phosphorus levels. African J of Agricultural 8(49):6401-6408

45. Tel-Zur N, Dudai M, Raveh E, Mizrahi Y (2011) In situ induction of chromosome doubling in vine cacti (Cactaceae). Scientia Horticulturae 129:570-576

46. Touchell DH, Palmer IE, Ranney TG (2020) In vitro Ploidy Manipulation for Crop Improvement. Front. Plant Sci. 11:722

47. Trick M, Long Y, Meng J, Bancroft I (2009) Single nucleotide polymorphism (SNP) discovery in the polyploid Brassica napus using Solexa transcriptome sequencing. Plant Biotechnology J 7:334-346

48. Tsuro M, Kondo N, Noda M, Ota K, Nakao Y, Asada S (2016) In vitro induction of autotetraploid of Roman chamomile (Chamaemelum nobile L.) by colchicine treatment and essential oil productivity of its capitulum. In Vitro Cell. Dev. Biol.-Plant 52:479-483

49. Van de Peer Y, Mizrachi E, Marchal K (2017). The evolutionary significance of polyploidy. Nat. Rev. Genet. 18, 411-424.

50. Wang LJ, Sheng MY, Wen PC, Du JY (2017) Morphological, physiological, cytological and phytochemical studies in diploid and colchicine-induced tetraploid plants of Fagopyrum tataricum (L.) Gaertn. Botanical Studies 58(1):2

51. Wei DX, Tang ZJ, Teixeira da Silva JA, Yu XN (2017) In vitro induction of polyploidy by colchicine treatment in herbaceous peony (Paeonia lactiflora Pall.). Acta Hort. 1171:265-278 
52. Wells R, Trick M, Soumpourou E, Clissold L, Morgan C, Werner P, et al. (2014) The control of seed oil polyunsaturate content in the polyploid crop species Brassica napus. Molecular Breeding 33(2):349362

53. Yang N, Rong E, Li Q, Dong J, Du T, Zhao X, Wu Y (2015) Tetraploid Induction and Identification of Gossypium arboreum. Agricultural Sciences 6(04):436

54. Zhang J, Pian R, Yang E, Zhou W, He Q, Chen X (2020) In vitro induction and characterization of tetraploid drumstick tree (Moringa oleifera Lam.) De Gruyter. Open Life Sciences 15: 840-847

55. Zar JH (1996) Biostatistical Analysis. Prentice Hall, Inc., Upper Saddle River, NJ, USA

56. Zeng Q, Liu Z, Kang D, Kang X (2019) Oryzalin-induced chromosome doubling in triploid Populus and its effect on plant morphology and anatomy. Plant Cell, Tissue, and Organ Culture 138:571-581. https://doi.org/10.1007/s11240-019-01654-y

\section{Tables}

Table 1 Effect of colchicine on induction of polyploid plants of Niger 


\begin{tabular}{|c|c|c|c|c|}
\hline \multirow[t]{2}{*}{ Colchicine treatment (\%) } & \multirow[t]{2}{*}{ Duration of treatment $(\mathrm{h})$} & \multirow[t]{2}{*}{ Survival rate $(\%)$} & \multicolumn{2}{|c|}{ No. of shoots with ploidy } \\
\hline & & & $2 n=2 x$ & $4 x$ \\
\hline \multirow{4}{*}{0.0} & 4 & 100 & 21 & - \\
\hline & 8 & 100 & 21 & - \\
\hline & 12 & 100 & 21 & - \\
\hline & 16 & 100 & 21 & - \\
\hline \multirow{4}{*}{0.005} & 4 & 88.8 & 9 & - \\
\hline & 8 & 80.9 & 9 & - \\
\hline & 12 & 85.7 & 9 & - \\
\hline & 16 & 77.7 & 6 & - \\
\hline \multirow{4}{*}{0.01} & 4 & 76.1 & - & - \\
\hline & 8 & 85.7 & 10 & 2 \\
\hline & 12 & 80.9 & - & 4 \\
\hline & 16 & 76.1 & - & 4 \\
\hline \multirow{4}{*}{0.02} & 4 & 47.6 & 7 & 3 \\
\hline & 8 & 61.9 & 8 & 5 \\
\hline & 12 & 52.3 & 6 & 5 \\
\hline & 16 & 47.6 & 6 & 4 \\
\hline \multirow{4}{*}{0.03} & 4 & 48.1 & 7 & - \\
\hline & 8 & 47.6 & 7 & 2 \\
\hline & 12 & 42.8 & 5 & 3 \\
\hline & 16 & 42.8 & 4 & 2 \\
\hline \multirow{4}{*}{0.04} & 4 & 28.5 & 9 & - \\
\hline & 8 & 33.3 & 9 & - \\
\hline & 12 & 23.8 & 9 & - \\
\hline & 16 & 23.8 & 9 & - \\
\hline
\end{tabular}

Table 2 Flow cytometric analysis of nuclear DNA size in leaf tissues and number of chromosomes in root tip cells of in vitro raised diploid control and colchicine induced tetraploid plantlets 


\begin{tabular}{|lllll|}
\hline Plant Sample & $\begin{array}{l}\text { X-Mean (Sample } \\
\text { G1 peak mean) }\end{array}$ & $\begin{array}{l}\text { 2C } \\
\text { DNA (Sample) } \\
(\mathrm{pg})\end{array}$ & $\begin{array}{l}\text { DNA } \\
\text { size (Mbp) }\end{array}$ & $\begin{array}{l}\text { Number of } \\
\text { chromosomes per } \\
\text { nuclei }\end{array}$ \\
\hline Diploid plant & 22770 & 4.70 & 4536 & $2 \mathrm{n}=2 \mathrm{x}=30$ \\
\hline $\begin{array}{l}\text { Colchicine } \\
\text { treated plant }\end{array}$ & 42337 & 10.34 & 9974 & $4 \mathrm{x}=60$ \\
\hline
\end{tabular}

Table 3 Characters of in vitro raised diploid (control) and colchicine induced tetraploid plants on transferred to natural conditions

\begin{tabular}{|c|c|c|c|}
\hline Parameters & Diploid plant & Tetraploid plant & \multirow{17}{*}{$\begin{array}{l}*=\text { characters noted at } \\
\text { first capitula } \\
\text { formation; fresh } \\
\text { weight and dry weight } \\
\text { were of whole plant } \\
\text { including root system; } \\
\star \star=\text { Ray floret also } \\
\text { fertile in Niger hence } \\
\text { seed from ray floret + } \\
\text { disc floret; Data } \\
\text { expressed in mean } \pm\end{array}$} \\
\hline Leaf area $\left(\mathrm{cm}^{2}\right)$ * & $24.7 \pm 0.7^{b}$ & $42.3 \pm 1.8^{\mathrm{a}}$ & \\
\hline Stoma width $(\mu \mathrm{m})$ & $15.1 \pm 0.4^{\mathrm{b}}$ & $28.6 \pm 0.8^{a}$ & \\
\hline Stoma length $(\mu \mathrm{m})$ & $24.3 \pm 0.6^{b}$ & $36.6 \pm 1.3^{a}$ & \\
\hline Stoma frequency on abaxial (lower) side & $39 \pm 0.5^{a}$ & $18.3 \pm 0.8^{b}$ & \\
\hline Stoma frequency on adaxial (upper) side & $26.6 \pm 0.8^{a}$ & $13.6 \pm 0.6^{\mathrm{b}}$ & \\
\hline Fresh weight $(\mathrm{g})^{\star}$ & $75.4 \pm 4.2^{b}$ & $83.3 \pm 1.8^{a}$ & \\
\hline Dry weight $(\mathrm{g})^{\star}$ & $8.12 \pm 0.5^{b}$ & $9.05 \pm 0.4^{\mathrm{a}}$ & \\
\hline Moisture content (\%) & $89.2 \pm 1.6^{\mathrm{a}}$ & $88.1 \pm 1.9^{\mathrm{a}}$ & \\
\hline Length of sepals $(\mathrm{mm})$ & $21.5 \pm 1.6^{b}$ & $37.4 \pm 1.4^{\mathrm{a}}$ & \\
\hline Diameter of capitula $(\mathrm{mm})$ & $36.4 \pm 1.3^{b}$ & $47.4 \pm 1.5^{\mathrm{a}}$ & \\
\hline Number of ray florets per capitula & $7.2 \pm 0.3^{b}$ & $9.0 \pm 0.5^{\mathrm{a}}$ & \\
\hline Number of disc florets per capitula & $29.6 \pm 0.8^{b}$ & $43.6 \pm 0.8^{a}$ & \\
\hline Number of seeds per capitula** & $33.6 \pm 2^{b}$ & $54 \pm 1.1^{\mathrm{a}}$ & \\
\hline Length of Ray floret along with ovary (mm) & $15.6 \pm 0.8^{b}$ & $19.6 \pm 0.8^{a}$ & \\
\hline Weight of 100 seeds (g) & $0.78 \pm 0.02^{b}$ & $0.82 \pm 0.05^{\mathrm{a}}$ & \\
\hline Oil content/10gram seeds (g) & $4.2 \pm 0.08^{\mathrm{b}}$ & $4.81 \pm 0.09^{a}$ & \\
\hline
\end{tabular}




\section{Outline of tetraploid generation}

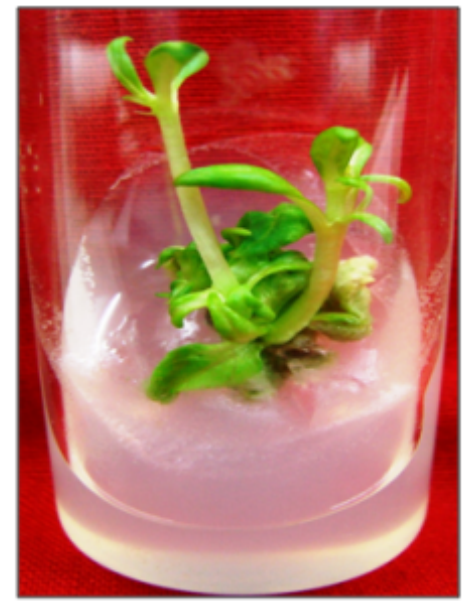

Diploid shoots on

$1.0 \mathrm{mg} / \mathrm{l} \mathrm{BAP}$

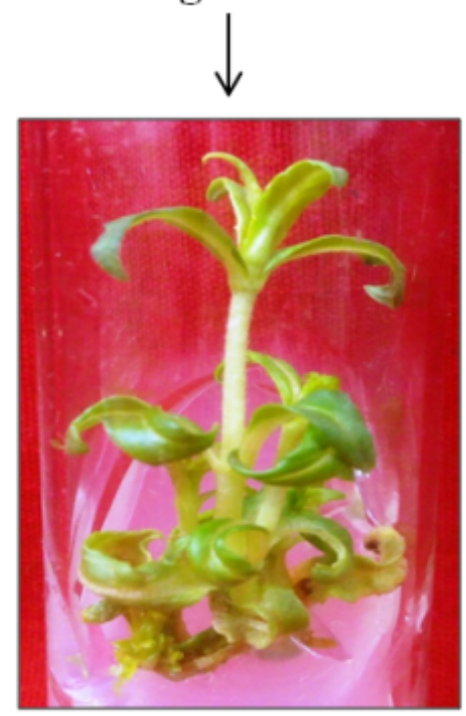

Shoots are similar to

diploids on $1.0 \mathrm{mg} / \mathrm{l}$ BAP

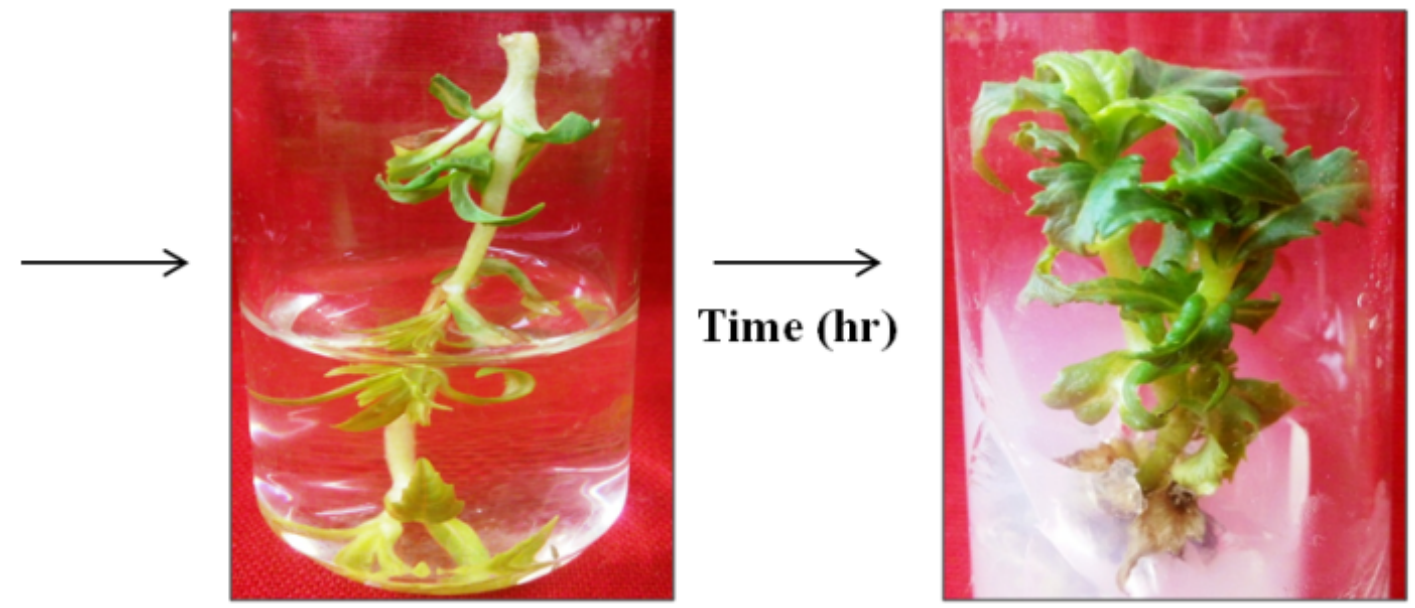

Apical shoot portion treated with $0.02 \%$ colchicine in MS $+1.0 \mathrm{mg} / \mathrm{l}$ BAP

\section{Colchicine induced} tetraploid shoots

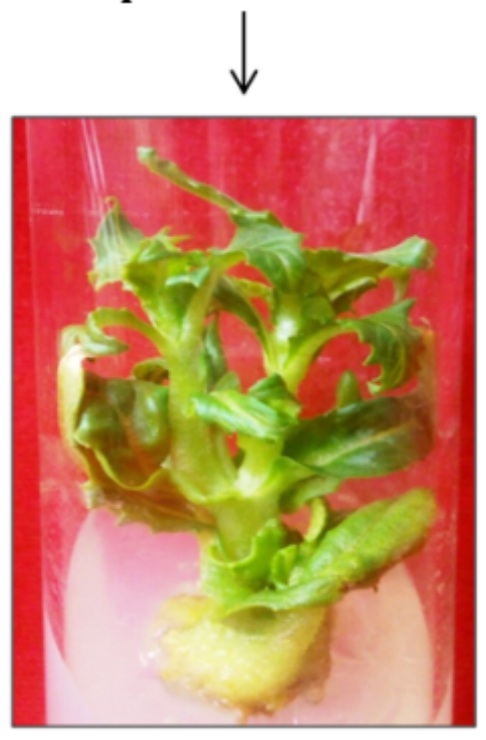

Shoots with tetraploid nature

Figure 1

In vitro induction of tetraploidy in apical portion of shoots of Guizotia abyssinica using colchicine 

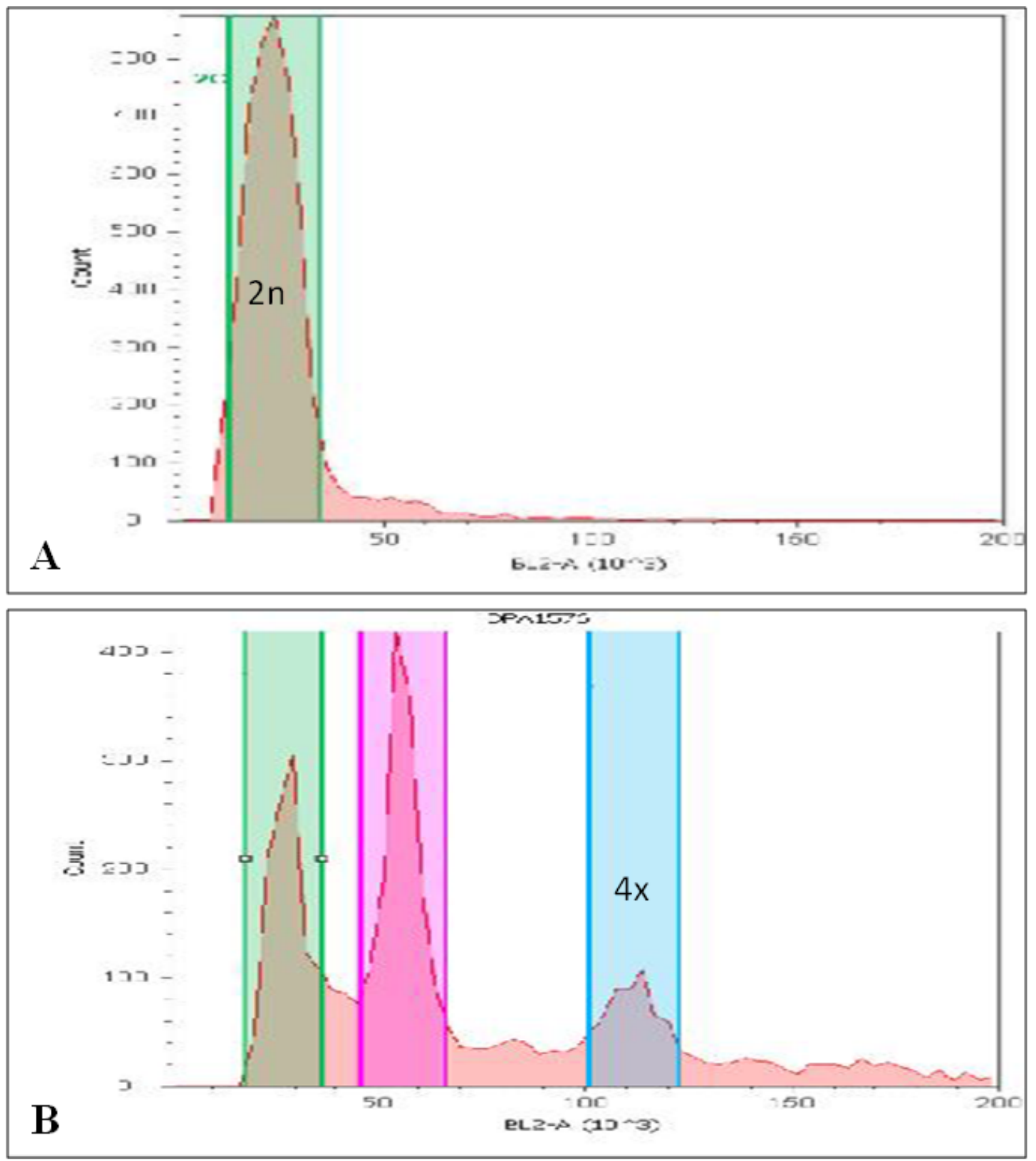

Figure 2

Histogram of flow cytometric analysis of leaf cell nuclear DNA content of $A$ in vitro raised control diploid (A) and colchicine induced tetraploid plants (B). Figure (A) and (B) showed relative DNA content on X-axis and number of events (counts) on Y-axis 

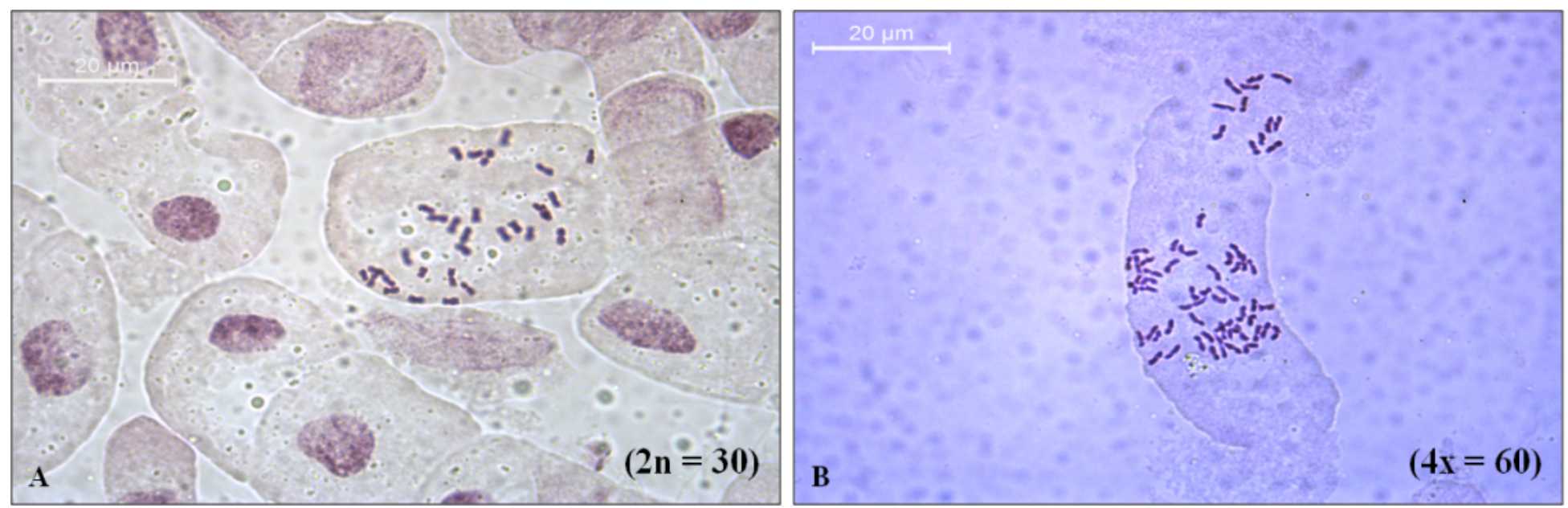

\section{Figure 3}

Chromosome numbers from root tip of in vitro raised diploid control (mitotic metaphase $2 n=30$ ) (A) and colchicine induced tetraploid (mitotic metaphase $4 x=60$ ) plants $(B)$
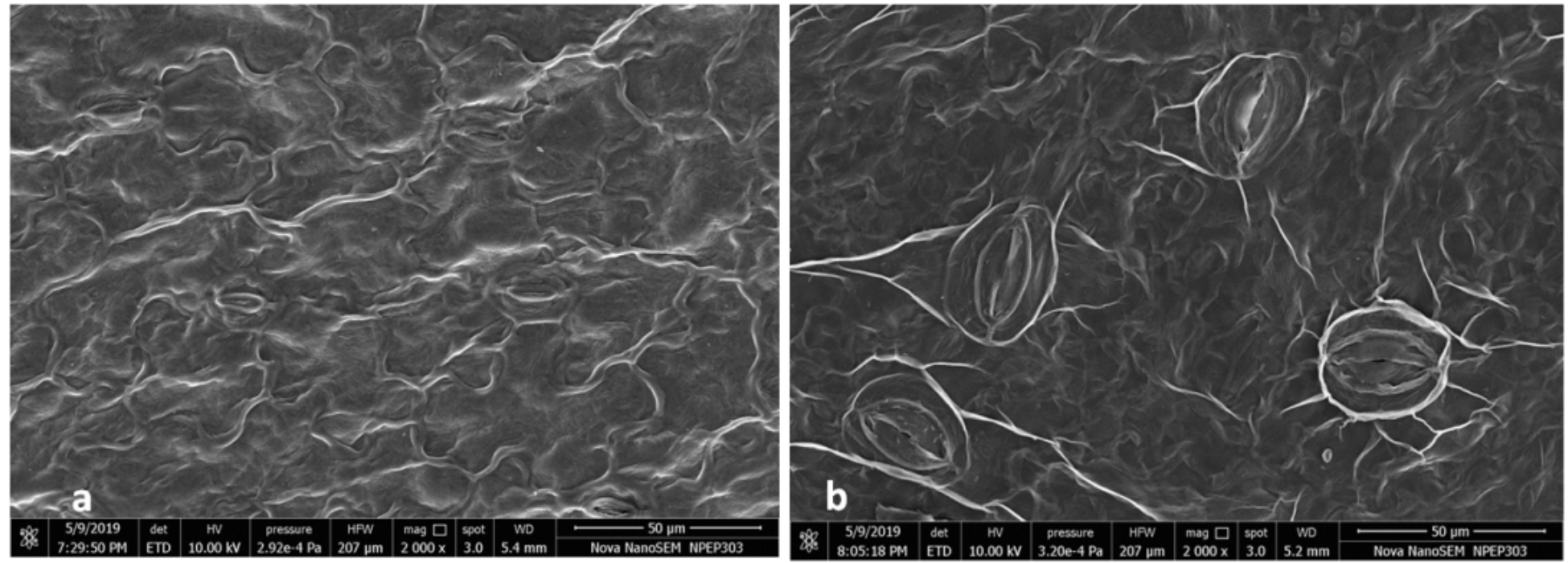

\section{Figure 4}

Stomatal size and density in lower leaf epidermis of in vitro raised control diploid (a) and tetraploid (b) Guizotia abyssinica plants 

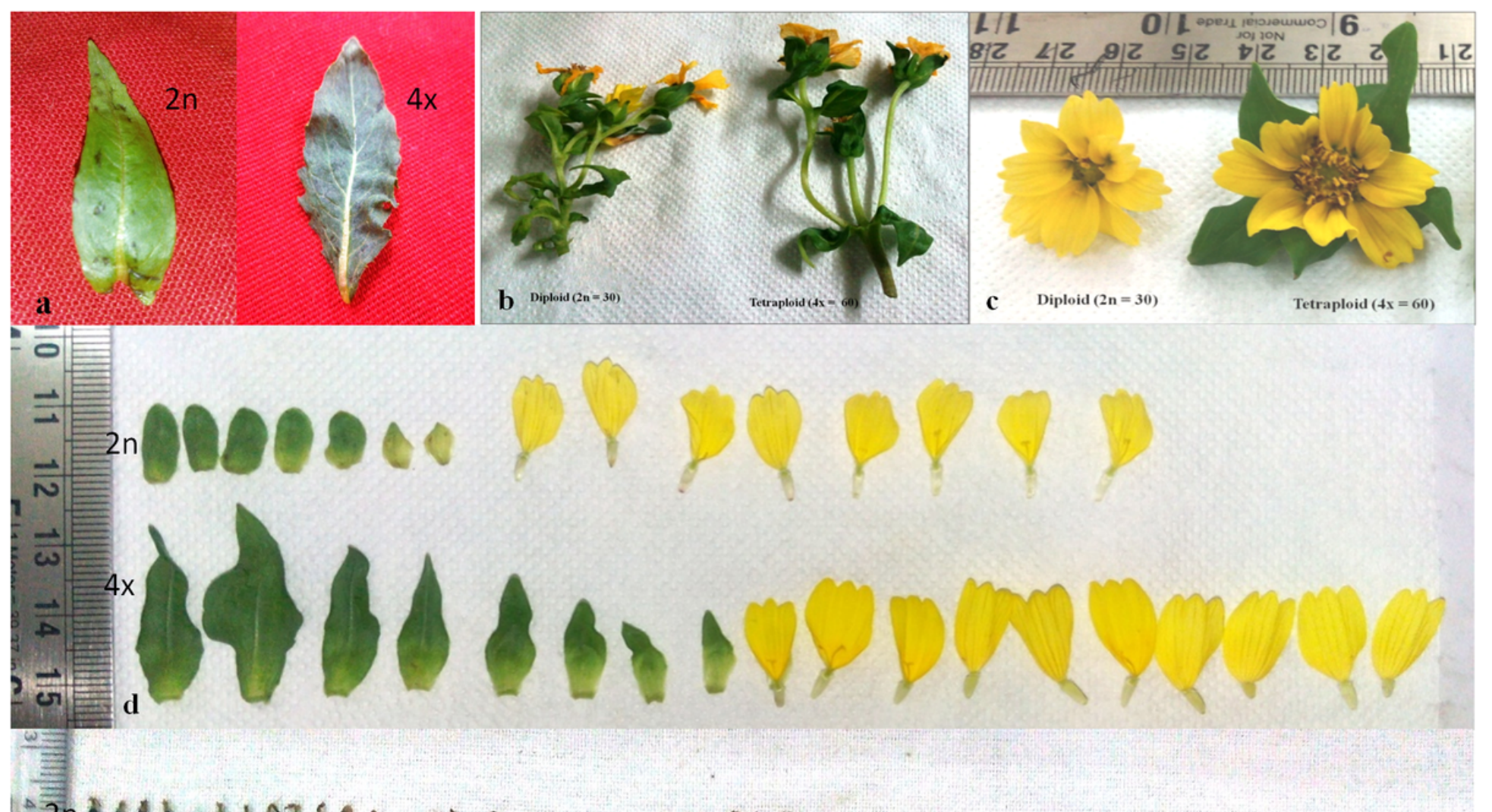

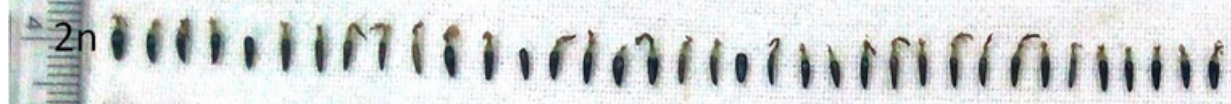

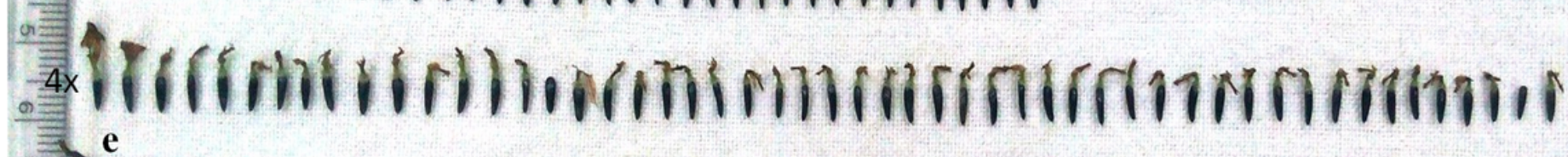

Figure 5

Morphological variations in in vitro raised diploid (control) and colchicine induced tetraploid plants after transferred to natural conditions. Leaf (a) Diploid (a) tetraploid (b), Floral shoot (b) control diploid (a), tetraploid (b), Inflorescence (c) control diploid (a), tetraploid (b), Sepals and ray florets (d) control diploid (a), tetraploid (b). Seeds (e) control diploid (a), tetraploid plant (b) 


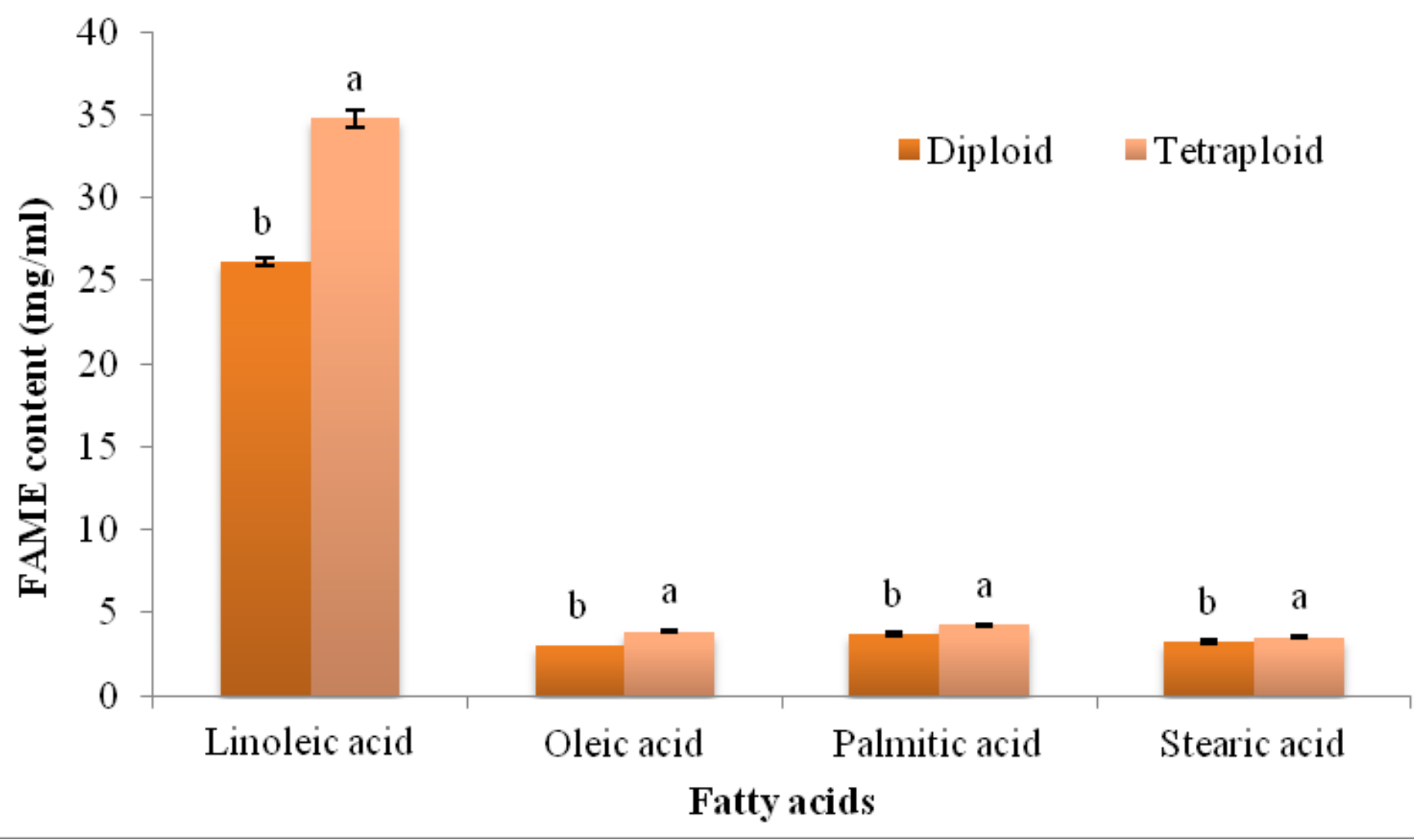

Figure 6

Fatty acid content in seed oil of in vitro raised control diploid and colchicine induced tetraploid plants of Guizotia abyssinica 


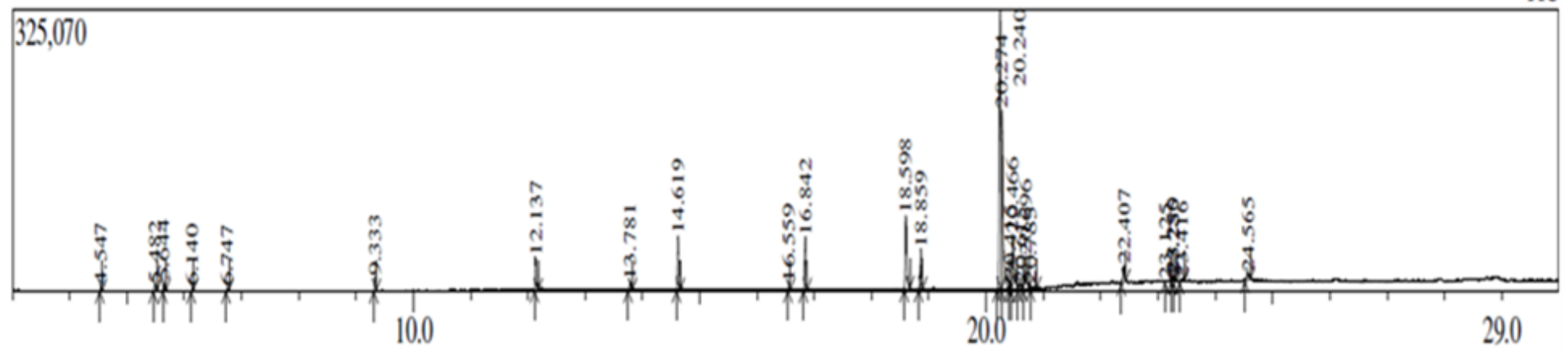

b

Chromatogram MGI C:UsersiAdminDesktop|HARN12.3.2019MGl.ggd

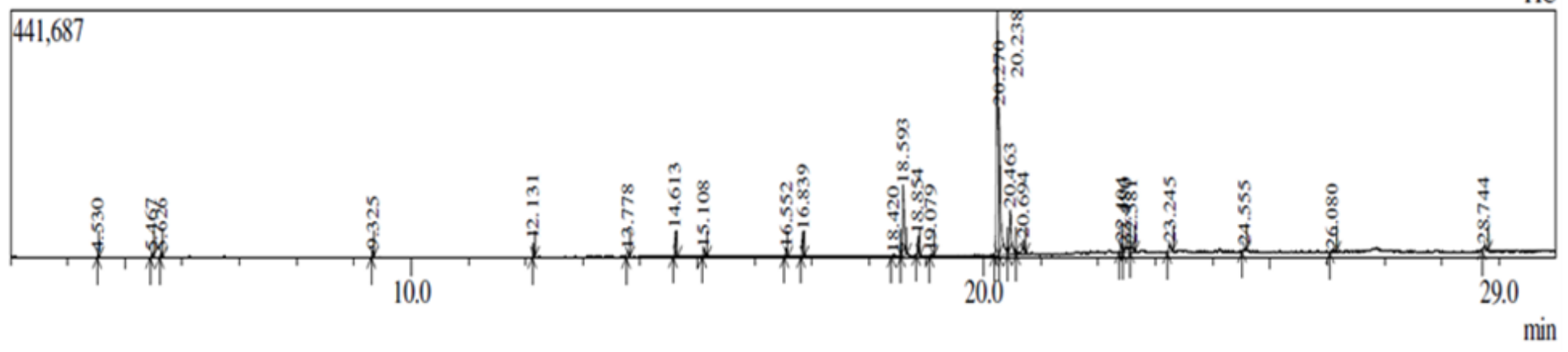

Figure 7

GC-MS analysis of Niger seed oil. Chromatogram showing fatty acids (linoleic, oleic, palmitic and stearic acid) content in Niger seed oil. control plant (a) (Retention time- linoleic acid (20.24), oleic acid (20.27), palmitic acid (18.59), and stearic acid (20.46)); tetraploid plant (b) (Retention time- linoleic acid (20.23), oleic acid (20.27), palmitic acid (18.59), and stearic acid (20.46)) 